\title{
THE EFFECT OF TOURISTS' MOTIVATIONS ON COGNITIVE, AFFECTIVE AND UNIQUE IMAGE OF BALI
}

\author{
Alita Prameswari \\ Faculty of Business and Economics, University of Surabaya \\ alitazhu@gmail.com \\ Christina Rahardja Honantha \\ Faculty of Business and Economics, University of Surabaya \\ crhonantha@gmail.com \\ Dudi Anandya \\ Faculty of Business and Economics, University of Surabaya \\ samkidud@gmail.com
}

Received: November, 2019; Accepted: July, 2020; Published: September, 2020

DOI: https://doi.org/10.24123/jmb.v19i2

\begin{abstract}
This research examines the effect of tourists' motivations on cognitive, affective and unique image of Bali. The model used for this study adopted from Llodra-Riere, et al. (2015). The variable of the study consists of information source, motivation, cognitive image, affective image and unique image. The model in this study used six hypotheses. This research is quantitative and causal type research. This study used non-probability and purposive sampling approach, sample characteristics are the Surabaya tourists who had experience in using information sources from internet platform and other information sources which is non-internet platform that been collected information before visiting Bali and have visited Bali at least once in the past one year. The data is obtained from questionnaire that is distributed to 310 respondents and analyze using Structural Equation Modeling (SEM), with SPSS 18 and LISREL 8.8 for measurement and structural model. The result shows that motivation did not influence affective image of Bali. There are five hypotheses are significant. Information sources influence motivation; cognitive image and unique image influence affective image; motivation influences cognitive image and unique image of Bali. The benefit of this research can help tourism industry in Bali to improve their marketing communication by using social media, website platform and online advertisement.
\end{abstract}

Keywords: information sources, tourists motivation, cognitive image, affective image and unique image

\section{Abstrak}

Tujuan penelitian adalah menguji pengaruh tourists' motivations on cognitive, affective and unique image of Bali. Model penelitian sesuai dengan penelitian Llodra-Riere, et al. (2015). Variabel penelitian terdiri dari information source, motivation, cognitive image, affective image and unique image dan model penelitian memiliki enam hipotesis. Desain riset kuantitatif dan tipe riset kausal. Tipe pengambilan sampel nonprobability dan purposive sampling approach. Responden adalah pria dan wanita yang memiliki pengalaman menggunakan sumber-sumber informasi dari media 
internet dan sumber-sumber informasi dari media non internet yang dikumpulkan sebelum berkunjung ke Bali, dan responden pernah mengunjungi Bali satu kali dalam satu tahun terakhir. Pengumpulan data menggunakan kuesioner dengan sampel sebesar 310 responden. Analisa data menggunakan Structural Equation Modeling (SEM), with SPSS 18 and LISREL 8.8 untuk model pengukuran dan model struktural. Hasil penelitian menunjukkan bahwa motivation tidak mempengaruhi affective image of Bali. Ada lima hipotesis yang signifikan. Information sources mempengaruhi motivation; cognitive image dan unique image mempengaruhi affective image; motivation mempengaruhi cognitive image dan unique image of Bali. Penelitian ini bermanfaat bagi industri pariwisata di Bali untuk mengelola dan memanfaatkan sumber-sumber informasi media sosial, website dan iklan online yang efektif mempengaruhi motivasi wisatawan ke Bali.

Kata Kunci: information sources, tourists motivation, cognitive image, affective image and unique image

\section{INTRODUCTION}

The Internet offered easiness in life such as giving effective and efficient for communication across the country, to seek information needed, playing games, using social media to express ideas or opinion, for education purposes, for promoting and expanding the business and many more. It is hard to find people not holding their gadgets and use the internet to seek information or for entertainment purposes, source: (AHSIPC, 2015). Furthermore, the internet also has proven to be the main backbone in the tourism industry where users are relying on the website for an activity such as online tickets and hotel reservations. One thing that boosted marketing in tourism industry is the presence of user-generated content (UCG) which defined as any form of content that was created by users of an online system or service, UCG gained its momentum during 1990s and 2000s where information availability through new technology platform has become more accessible, user friendly, and affordable. UCG in the tourism industry works in the way that tourists can now share their past experiences of visiting a destination in social media and those contents would be further consumed by another tourist (Oz 2015).

The major activity is done by people when the gadget connected with internet connection is to use and access social media as information source based on figure 1. More than $87 \%$ of internet users in Indonesia access their social media account when having an internet connection. Besides access the social media, the next common activity done by internet users is search for information by searching and browsing. This behavior occurs especially when people wants to buy products, first, look for reviews regarding the products in the internet using a search engine such as google.com or yahoo.com; then data gathered by user are used as a consideration whether to make the purchase or not. Thus, it can be concluded that business that utilizes the internet, social media and search engine will be beneficial.

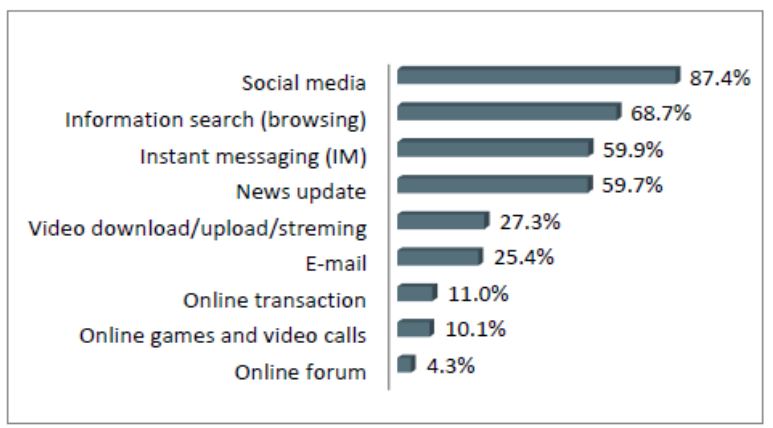




\section{Figure 1. Consumer Behavior for Internet Connection}

Source: blog.idkeyword.com

Tourists' did not only use internet as their main information sources, but noninternet information sources such as brochures, information from relatives, magazines \& newspapers as well as the book also used by tourists to collect information about destination tourists also want to visit. Tourists' also consult to internet and non-internet as information sources before deciding to visit a place. TripAdvisor.com, a website that provides reviews of travel-related content and is an example of a user-generated content website, recently chooses Bali as number \#1 destination of 2017 in the world. Bali offered several advantages over another destination, for instance; cheap destination followed with proximity which is easy to reach by tourists, offers a diverse range of hotels based on the stars as well as price, since the island is easy to reach, the transportation to visit Bali also has affordable price if compared with transportation price to Raja Ampat which also offered same beautiful beach destination like Bali.

According to (Chang et al. 2014) Motivation has been identified as a significant determinant of behavioral intentions in visiting tourism destinations. Image is the result of a mental process when individuals create a mental representation regarding the destination and based on the previous information (Gartner 1993). (Buyong \& Rajiani 2011) said due to a wide variety of information tourists stored in mind, only three main types of association which is; cognitive image, affective image, and unique image. According to (Baloglu 1999), cognitive image refers to beliefs and knowledge about an object whereas affective image refers to feelings about the object. Where unique image is the attributes or characteristics makes the destination is differentiated from another destination (Buyong and Rajiani 2011). A series of destination shape the image of tourism destinations attributes that are influenced by the personal characteristics of the individual or internal factors such as existing motivations, impressions, beliefs, opinions, preference of product, knowledge, which continues to be accumulated from various memorable tourism experiences on the image attributes of tourism destinations (Kim and Chen 2016).

The influence of travel motivation to the destination image supported by previous research such as Chang et al. (2014), Khan et al. (2017), Kim and Chen (2016), Pratminingsih et al. (2014), Prayag and Ryan (2011). Llodra-Riere et al., (2015), the indicator of destination image which consists of cognitive, affective and unique image are affecting one to another. Affective image is the image created in tourist mind by the feeling arouse from place, environment and the people. Moreover, unique image play an important role to affective image due to its influence on differentiation among destinations in the target customers' mind which is affective image. Therefore, can be concluded that unique image will significantly influence affective image. However, even though (Llodra-Riere et al. 2015) on its study proposed the hypothesis related unique image could influence affective image, the result is unique image did not positively influence the formation of affective image. The result is in contrast with some previous research conducted by (Qu et al. 2011) which indicate that unique image is positively influenced the overall image that consist of cognitive image and affective image. (Qu et al. 2011) stated on its paper that the unique image of a destination has a positive influence on cognitive and affective image. This caused a gap due to similar research model which consist of cognitive, affective and unique image, but the result of hypothesis is different based from (Llodra-Riere et al., 2015) and (Qu et al., 2011).

Llodra-Riere, et al. (2015), the indicator of destination image which consists of 
cognitive, affective and unique image are affecting one to another. Affective image is the image created in tourist mind by the feeling arouse from place, environment and the people. Moreover, unique image play an important role to affective image due to its influence on differentiation among destinations in the target customers' mind which is affective image. Therefore, can be concluded that unique image will significantly influence affective image. However, even though Llodra-Riere, et al. (2015) on its study proposed the hypothesis related unique image could influence affective image, the result is unique image did not positively influence the formation of affective image. The result is in contrast with some previous research conducted by Qu et al. (2011) which indicate that unique image is positively influenced the overall image that consist of cognitive image and affective image. Qu et al. (2011) stated on its paper that the unique image of a destination has a positive influence on cognitive and affective image. This caused a gap due to similar research model which consist of cognitive, affective and unique image, but the result of hypothesis is different based from LlodraRiere, et al. (2015) and Qu et al. (2011).

The research gap are study conducted by Llodra-Riere, et al. (2015), proposed that unique image will significantly influence affective image. However, the result was unique image did not positively influence the formation of affective image. Previous research conducted by Qu et al. (2011) which indicate that unique image is positively influence overall image that consist of cognitive image and affective image.

The research problem (1) Does information source influence tourist motivation for visiting Bali? (2) Does cognitive image influence affective image of Bali? (3) Does unique image influence affective image of Bali? (4) Does tourist' motivation influence the cognitive image of Bali? (5) Does tourist' motivation influence the affective image of Bali? (6) Does tourist' motivation influence the unique image of Bali? The purpose of this research are (1) to investigate the significant influence of information sources toward tourists' motivation for visiting Bali; (2) to investigate the significant influence of cognitive image toward the formation of affective image; (3) to investigate the significant influence of unique image toward the formation of affective image; (4) to investigate the significant influence of tourists' motivation toward cognitive image of Bali; (5) to investigate the significant influence of tourists' motivation toward affective image of Bali; (6) to investigate the significant influence of tourists' motivation toward unique image of Bali

Tourists' acquire information that allows them to know and evaluate the purchase alternative and thereby reduce the risk and uncertainty associated with that decision they made. (Gartner 1993) said that information lets individuals construct mental image regarding the destination before visiting and form expectations about the expected benefits and finally deciding if they want to visit the destination. According to (Kozak and Kozak 2008), information searches namely internal and external sources. Internal sources are information that comes from the person's knowledge and experience about the object, while external sources are information obtained from basic sources such as neutral (e.g. tourist office, travel guides), commercial (e.g. travel agents, brochures), social (e.g. relatives and friends), and media (e.g. newspaper, radio, TV, internet). Tourists can look to movie icons such as natural scenery, historical background, story lines and themes, actors, symbolic content, and human relationships, which must be distinguishable from other movie productions as part of information sources (Eleonora, P. \& Di Pietro, L. 2013).

Motivation refers to a need to act in different ways to achieve the desired satisfaction. Motivations are a dynamic concept that varies accordingly toward the person or market segment (Kozak (2002) instead of Correia et.al (2013)). Tourists' motivations are defined as a state of mind that encourages one to travel while able to 
provide a valid explanation for this decision to travel (Correia et al. 2013). Zhang et al. (2017) to know about what encourages tourists to visit a destination because the drive for a vacation arises from the need for something that can fulfill from traveling. The approach to this phenomenon is the travel motivation as it is a fundamental factor in knowing the tourist's behavior. (Gartner 1993) mentioned two sources of motivation of individual including internal source (push) and external source (pull) motivations to travel. Internal source (push) motivations include a desire to travel, rest, prestige, adventure, social interaction, and health and physical care. While external source (pull) motivations include the attractiveness of tangible resources of the destination such as beaches, cultural attractions, and recreational activities and the perceptions and expectations of travelers (novelty, profit expectations, and image marketing). Study by Adams et al. (2015) mentioned purchases and motivations for visiting a destination including shopping, image of destination, food and security and desire for a break from routine and everyday activities and a chance to experience new and different culture.

Cognitive Image. Refers to the beliefs or knowledge a person has of the characteristics or attributes of a tourist destination (Baloglu 1999). Qu et al. (2011) agree on quality perceived as a part of the formation of the cognitive image. Information regarding destination environment will be interpreted by tourist first and then used to categorize the tourist's emotional states, for instance; leisure, sports, and sun and sea activities. People will first receive the expected quality of the destination and then afterward, cognitive image will be created based on these expectations. Cognitive image itself is the very first process of a whole image formation process.

Affective Image. Refers to the feelings aroused by a place, people with different motives may assess a destination similarly if its perception satisfies their needs (Beerli \& Martin 2004). The derived feeling from visiting the destination is the factor that creates an expectation from affective image. Affective attribute such as unpleasant and pleasant feeling is indicated as an internal factor of tourists feeling. Physic atmosphere, accessibility, and personality factors are the example of important point and items use to measure the image of affective for destination images.

Unique image defines what attributes or characteristics make destination to be differentiated from competing destinations by tourists and a strong unique image would increase the favorability of the destination (Buyong \& Rajiani 2011). Qu et al., (2011) indicates that unique image can influence affective image formation.

Buyong \& Rajiani (2011) shows that unique image forming is considered as a special and inseparable construct from affective image that plays important role due to its influence on tourists' mind to differentiate one destination among other destinations. Echtner and Ritchie (1991) in Buyong \& Rajiani (2011) indicate how attributes make the unique image will depend on the destination and this unique image will differentiate one destination with others. Thus, uniqueness or unique image is particularly important for tourist due to its influence on differentiation and specialness about places among similar destinations in the target consumers' minds.

The Effect of Information Sources on Motivation for Travelling. According to Llodra-Riere, et al. (2015), there have been numerous studies that analyze the defining effect of the sources of information used in tourists' decision-making processes and also the use of different sources of information influences on tourists' motivation to visit a destination. Furthermore, Llodra-Riere, et al. (2015) indicates how sometimes the natures of persuasive of information obtained, when transmitted through the right channels and target the right audience, we're used to trying to change behavior of tourists and therefore had an impact on motivation. $\mathrm{H} 1$ : Information sources influence the motivations for traveling to Bali. 
The Effect of Cognitive Image on Formation of Affective Image. According to Gartner (1993), the interrelationship of cognitive and affective image components eventually determines the predisposition for visiting a destination. Information about an environment is first interpreted and made meaningful cognitively, then used to categorize the internal, emotional state which effectively. Therefore, interpretation of information rather than information itself produces an affective state. Furthermore, Llodra-Riere, et al. (2015) stated there is a large influence regarding the cognitive image that has a strong influence on affective image. $\mathrm{H} 2$ : Cognitive image influences the formation of affective image of Bali.

The Effect of Unique Image on Formation of Affective Image. Adequate information that uniqueness or unique image forming influences tourists of why they should choose one destination over other destinations. Qu et al., (2011) and LlodraRiere, et al. (2015) stated unique image influences affective image formation, uniqueness provides tourists with underlying reasons of why they should select one destination over other destinations. Thus, the uniqueness of destination associations to the tourists keeps in memory which means the factor of affective image. H3: Unique image influences the formation of affective image of Bali.

The Effect of Tourist' Motivations on Formation of Cognitive Image and Affective Image. Research Beerli \& Martin (2004) indicate that: (1) motivations influence the affective component of the image; (2) holiday tour experience has a significant relationship to cognitive and affective images; and (3) sociodemographic conditions influence the cognitive and affective evaluation of the image. Therefore, Beerli \& Martin (2004) concluded that the perceived image or cognitive image will be formed through the image projected by the destination and the individual's own needs, motivations, prior knowledge, preferences, and other personal characteristics. Qu et al., (2011) indicates that unique image can influence affective image formation. H4: Motivations influence the formation of cognitive image of Bali. H5: Motivations influence the formation of affective image of Bali.

The Effect of Tourist' Motivations on Formation of Unique Image. Buyong \& Rajiani (2011) indicated that unique image is significantly constructed and affected by cognitive and affective image evaluations. Wu \& Zheng (2014) also indicated a similar response toward unique image, they mentioned that unique image can attract tourists and make a positive impression on them and encourage greater loyalty to revisit the destination. Thus, while both cognitive and affective image significantly construct unique image, both cognitive and affective also directly influence by motivation, which further indicates that motivation indeed also influence unique image formation, especially in terms of revisit motivation. H6: Motivations influence the formation of unique image of Bali. 


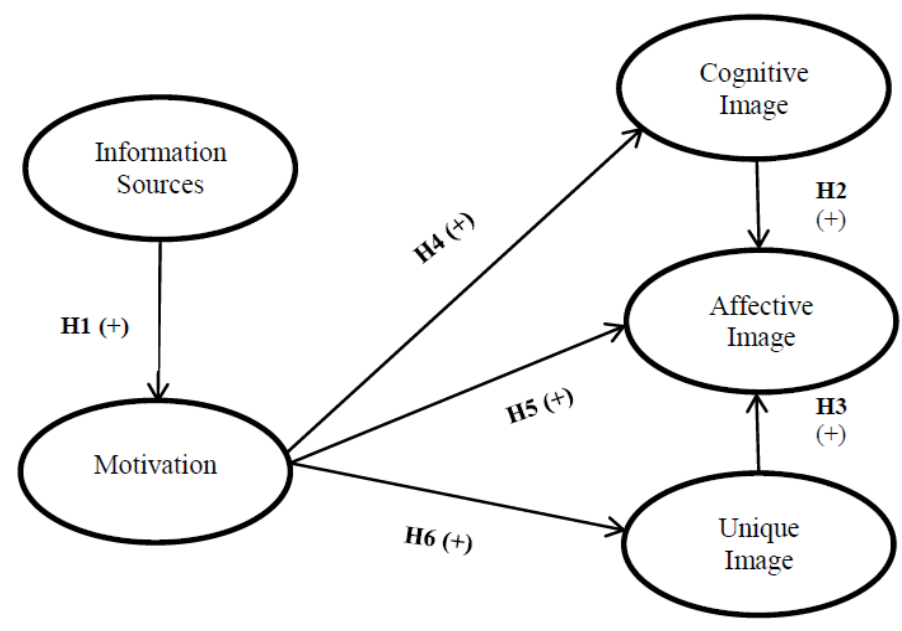

Figure 2. Research model

Source: Llodra-Riere, et al. (2015)

\section{RESEARCH METHODS}

This research is quantitative research with a causal relationship between the variables as the approach. Variables used in this study are information source which consist of web platform and social media, motivation, cognitive image, affective image and unique image of Bali in Surabaya. This research uses primary data which collect directly from the source through a questionnaire. In sampling technique, this research uses the non-probability sampling. The characteristic of the population is male or female with minimum age is tourist 18 years old or above who use information sources from internet platform and had use minimum 3 information sources which is a noninternet platform to collect information regarding the destination and have visited Bali at least once in the past 1 year.

Data that has been collected will be processed using Structural Equation Model (SEM) by using SPSS and LISREL as the tools. However, validity test and reliability tests must be processed first to know the validity of each indicator in the questionnaire and the reliability of its indicator to its variables. Then, confirmatory factor analysis will run to see whether the model is suitable and meet the requirement of goodness of fit as model fit, which was: CMIN/DF (The Minimum Sample Discrepancy Function), The Root Mean Square of Approximation (RMSEA), Goodness of Fit Index (GFI), Adjusted Goodness of Fit Index (AGFI), Tucker Lewis Index (TLI) and Comparative Fit Index (CFI). The hypothesis testing against each parameter will be done by using t-test. Null hypothesis of the t-test states that each parameter tested score $=0$, and the alternative hypothesis states that each parameter tested score $\neq 0$. Thus, null hypothesis will be rejected if the value of $|t| \geq 1.96$ and alternative hypothesis will be accepted.

\section{RESULT AND DISCUSSIONS}

The spreading of data respondents is based on gender. Female respondents are $55.5 \%$ and male respondents are $44.5 \%$. Motives for visiting Bali are holiday $69,4 \%$; meet relatives $13,2 \%$; work $11 \%$ and others. Total respondents are 310 .

Table 1. Socio-demographic respondents

\begin{tabular}{llcr}
\hline Gender & Male & 138 & $44.5 \%$ \\
& Female & 172 & $55.5 \%$ \\
Age & $18-25$ years old & 182 & $58.7 \%$ \\
& $26-35$ years old & 93 & $30 \%$
\end{tabular}




\begin{tabular}{clcr} 
& $36-45$ years old & 22 & $7.09 \%$ \\
& $46-55$ years old & 13 & $4.2 \%$ \\
& Entrepreneur & 45 & $14.5 \%$ \\
Occupations & Private Employee & 122 & $39.4 \%$ \\
& Students & 119 & $38.4 \%$ \\
& Unemployed & 14 & $4.5 \%$ \\
& Others & 10 & $3.20 \%$ \\
& Event & 17 & $5.5 \%$ \\
Motives for & Holiday & 215 & $69.4 \%$ \\
visiting & Meet relatives & 41 & $13.2 \%$ \\
& Ministry & 1 & $0.3 \%$ \\
& Pray & 2 & $0.6 \%$ \\
Source: Data processed by SPSS & 34 & $11 \%$ \\
\hline & Work & &
\end{tabular}

The analysis of the measurement model is conducted by using Confirmatory Factor Analysis (CFA). First stage of processing data in done through first-order confirmatory factor analysis which the purpose to identify which indicator should be eliminated and which indicator remains to represent the variable.

There are nine-factor loadings from twenty-five indicators of Information sources under 0.5 which is the minimum standard. These nine indicators which have factor loading under 0.5 will be deleted to make the result suits with the requirement of model fit. The early stage of information source, CFA has the value of Goodness-Of-Fit (GOF) which fulfill the suitable criteria (CMIN/DF $=2.760, \mathrm{RMSEA}=0.075, \mathrm{GFI}=0.89$, $\mathrm{TLI}=0.96$, and $\mathrm{CFI}=0.96)$. which is under the requirement (RMSEA $\leq 0,08)$ and $($ CMIN/DF $\leq 3)$.

There are three indicators from twenty-five Motivation which the factor loading is below 0.5. The CFA of motivation has the value of Goodness-Of-Fit (GOF) which fulfill the suitable criteria (CMIN/DF $=2.844, \mathrm{RMSEA}=0.077, \mathrm{GFI}=0.85, \mathrm{TLI}=0.96$, and $\mathrm{CFI}=0.97$ ).

The CFA indicate that there are two indicators from fifteen indicators of Cognitive Image which the factor loading is below 0.5. The value of Goodness-Of-Fit (GOF) which fulfill the suitable criteria (CMIN/DF $=2.251, \mathrm{RMSEA}=0.064, \mathrm{GFI}=0.94, \mathrm{TLI}=$ 0.98 , and $\mathrm{CFI}=0.98$ ).

The CFA indicate that there are six indicators from twenty-seven indicators of Affective Image which the factor loading is below 0.5. Thus, six indicators that have factor loading under 0.5 will be deleted to make the result better. The value of Goodness-Of-Fit (GOF) which fulfill the suitable criteria (CMIN/DF $=2.414$, RMSEA $=$ $0.068, \mathrm{GFI}=0.89$, $\mathrm{TLI}=0.98$, and $\mathrm{CFI}=0.98$ ).

The CFA indicate that there are six indicators from fifteen indicators of Unique Image which the factor loading is below 0.5. Thus, six indicators that have factor loading under 0.5 will be deleted to make the result better. The value of Goodness-OfFit (GOF) which fulfill the suitable criteria (CMIN/DF $=2.933, \mathrm{RMSEA}=0.079, \mathrm{GFI}=$ $0.95, \mathrm{TLI}=0.97$, and $\mathrm{CFI}=0.98)$.

Table 2. Variance Extracted and Construct Reliability Result

\begin{tabular}{|c|c|c|c|c|c|c|c|c|c|}
\hline Dimension & $\lambda$ & $\lambda^{2}$ & $\mathbf{e}_{\mathbf{i}}$ & $\Sigma \lambda$ & $(\Sigma \lambda)^{2}$ & $\Sigma\left(\lambda^{2}\right)$ & $\Sigma \mathbf{e}_{\mathbf{i}}$ & CR & AVE \\
\hline \multicolumn{10}{|l|}{ Information Source } \\
\hline FINFO1 & 0.7 & 0.49 & 0.51 & & & & & & \\
\hline FINFO2 & 0.76 & 0.58 & 0.42 & 2.86 & 8.18 & 2.05 & 1.95 & 0.81 & 0.51 \\
\hline FINFO3 & 0.76 & 0.58 & 0.42 & & & & & & \\
\hline FINFO4 & 0.64 & 0.41 & 0.59 & & & & & & \\
\hline \multicolumn{10}{|l|}{ Motivation } \\
\hline MOTI1 & 0.72 & 0.52 & 0.48 & & & & & & \\
\hline MOTI2 & 0.71 & 0.5 & $\begin{array}{l}0.5 \\
0.12\end{array}$ & 2.85 & 8.12 & 2.04 & 1.96 & 0.81 & 0.51 \\
\hline MOII3 & 0.16 & 0.58 & 0.42 & & & & & & \\
\hline
\end{tabular}




\begin{tabular}{|c|c|c|c|c|c|c|c|c|c|}
\hline MOTI4 & 0.66 & 0.44 & 0.56 & & & & & & \\
\hline Cognitive Image & 061 & O41 & 059 & & & & & & \\
\hline CIMAG2 & $\begin{array}{l}0.64 \\
0.78\end{array}$ & $\begin{array}{l}0.41 \\
0.61\end{array}$ & $\begin{array}{l}0.59 \\
0.39\end{array}$ & 2.95 & 8.7 & 2.19 & 1.81 & 0.83 & 0.55 \\
\hline CIMAG3 & 0.77 & 0.59 & 0.41 & & & & & & \\
\hline CIMAG4 & 0.76 & 0.58 & 0.42 & & & & & & \\
\hline Affective Image & & & & & & & & & \\
\hline AIMAG1 & 0.7 & 0.49 & 0.51 & & & & & & \\
\hline AIMAG2 & 0.76 & 0.58 & 0.42 & & & & & & \\
\hline AIMAG3 & 0.8 & 0.64 & 0.36 & 4.58 & 20.98 & 3.51 & 2.49 & 0.89 & 0.58 \\
\hline AIMAG4 & 0.77 & 0.59 & 0.41 & & & & & & \\
\hline AIMAG5 & 0.82 & 0.67 & 0.33 & & & & & & \\
\hline AIMAG6 & 0.73 & 0.53 & 0.47 & & & & & & \\
\hline Unique Image & & & & 2.38 & 5.66 & 1.89 & 1.11 & 0.84 & 0.63 \\
\hline
\end{tabular}

Based on table 2 can be seen that the value of each variable for AVE in this study was greater than 0.5 . Also, the value of the CR for each variable in this study is greater than 0.7 . This indicates that each variable in this study has fulfilled both the value of AVE or CR.

In table 2, all of the goodness of fit is meet the requirement, the crucial index which is CMIN/DF and RMSEA also have value under the maximal number of requirement. Thus, the model of this research is classified as Good Fit due to the fulfillment of each fitness test index as well as the results.

Table 3. Goodness of Fit Indexes

\begin{tabular}{clllc}
\hline No & Fitness Test & Term of Use & Result & Explanation \\
\hline 1 & CMIN/DF & CMIN/DF $\leq 3$ (Good Fit) & 2.741 & Good Fit \\
2 & RMSEA & RMSEA $\leq 0,08$ (Good Fit) & 0.075 & Good Fit \\
3 & GFI & $\begin{array}{l}\text { GFI } \geq 0,90 \text { (Good Fit) 0,80 } \\
\text { (GFI } \leq 0,90\end{array}$ & & Marginal Fit \\
& & (Marginal Fit) & 0.87 & \\
4 & AGFI & AGFI $\geq 0,90$ (Good Fit) & & Marginal Fit \\
5 & TLI/NNFI & $0,80 \leq$ AGFI $\leq 0,90$ (Marginal Fit) & 0.83 & Good Fit \\
6 & CFI & CFI $\geq 0,90$ (Good Fit) & 0.96 & Good Fit \\
\hline
\end{tabular}

Source: Lisrel 8.8 output

In this hypothesis testing, the test will be done by tested the coefficients of structural equations by specifying a certain level of significance. This research used $\alpha$ $=0.05$, furthermore, the critical ratio of the structural equation should be $|t| \geq 1.96$. Based on the results of the processing of the output of the SEM has been processed, the result of the correlation coefficient value is obtained as follows:

\begin{tabular}{ccccc}
\multicolumn{5}{c}{ Table 4. Hypothesis Testing Result } \\
\hline Hypothesis & Path & ST. Estimate & t-value & Result \\
\hline H1 & INFO MOTI & 0.66 & 9.29 & Supported \\
H2 & CIMAG AIMAG & 0.39 & 5.90 & Supported \\
H3 & UNIQ AIMAG & 0.64 & 9.06 & Supported \\
H4 & MOTI CIMAG & 0.54 & 6.91 & Supported \\
H5 & MOTI AIMAG & 0.05 & 0.84 & Not Supported \\
H6 & MOTI UNIQ & 0.46 & 6.48 & Supported \\
\hline
\end{tabular}

Source: Lisrel 8.8 output

Based on table 4, the hypothesis testing result can be explained as follows. Information Sources affecting on Motivation of tourists in Bali and has the value standardized estimate of 0.66 with $t$-value of 9.29 which is greater than the 
requirement $(|t| \geq 1.96)$. Hypothesis one is significant. It can be concluded that the more complete information provided by information sources, the level of tourist motivation to visit Bali will be increasing. Furthermore, information source has successfully influence and/or creating motivation of tourists to travel to Bali.

Cognitive Image affecting on Affective Image of tourists in Bali and has the value standardized estimate of 0.37 with $t$-value of 5.90 which is greater than the requirement $(|t| \geq 1.96)$. Hypothesis two is significant. It can be concluded that cognitive image that Bali has it will successfully influence and/or creating affective image of tourists. Furthermore, by successfully influence tourists' affection, it can lead to re-visit action rather than visiting another island besides Bali.

Unique Image affecting on Affective Image of tourists in Bali and has the value of standardized estimate of 0.64 with $t$-value of 9.06 which is greater than the requirement $(|t| \geq 1.96)$. Hypothesis three is significant. Thus, can be portrayed that unique image has successfully influence and/or creating affective image of tourists. It means that the more unique the destination or places is, the more affection tourist feel about the place. Same goes for Bali. Bali was known for unique place and destination, if the government or tourism industry keep developing or creating a new unique destination in Bali, then every tourist that come to Bali will have the affection of the place regarding the unique image.

Motivation affecting on Cognitive Image of tourists in Bali and has the value of standardized estimate of 0.54 with t-value of 6.91 which is greater than the requirement $(|t| \geq 1.96)$. Hypothesis four is significant. Furthermore, based on the hypothesis result and literature review stated above, can be concluded that tourism industry in Bali has successfully created motivation of its tourist about Bali and influence the formation of cognitive image regarding Bali. It means that the more motivation tourist had for visiting destinations, the more cognitive image will have in return.

Motivation affecting on Affective Image of tourists in Bali and has the value of standardized estimate of 0.05 with $\mathrm{t}$-value of 0.84 which is lower than the requirement $(|t| \geq 1.96)$. This hypothesis is not significant. Motivation might directly or indirectly influence affective image since the factor that forms tourist motivation is diverse; depends on the psychological force in tourists (Baloglu \& McCleary (1999) instead of Llodra-Riere, et al. (2015)). Thus, the result of this research might be different if the motivation is indirectly influenced affective rather than motivation directly influence affective image.

Motivation affecting on Unique Image of tourists in Bali and has the value of standardized estimate of 0.46 with $t$-value of 6.48 which is greater than the requirement $(|t| \geq 1.96)$. Hypothesis six is significant. Motivation has influences in unique image of Bali. It means that Bali is unique islands that have several unique places which make the island is different from another island in Indonesia. This uniqueness of Bali might trigger the motivation of tourists to visit Bali and if the tourist were satisfied with the unique image offered by Bali, tourist will develop the motivation and intention to revisit the island rather than another destination.

This research is a causal relationship which according to Hair et al. (1998) is dependence relationship between two or more variable in which the researcher specifies that one or more variable cause or create an outcome represented by at least one other variable must meet the requirement for causation. This research has five variables consist of; information sources, motivation, cognitive image, affective image, and unique image. Based on the research model, information sources are crucial and play an important role as information sources are the independent variables that give a direct influence on motivation as well as to the other variables. 
While the end of the research model's narrow is on affective images which are interesting to identify why affective image is the end of the models.

These six-hypothesis research result on table 4 can be explained, first is supported literature review conducted by Llodra-Riere, et al. (2015), stated that information source will influence tourists' motivation for traveling to Bali. Tourists' motivation is created by perceived needs that being mediated by situational influences, including promotional information and word-of-mouth (WOM) stated by Chang et al. (2014). Second is supported by literature review conducted by Llodra-Riere, et al. (2015) and Buyong \& Rajiani (2011), it is stated that cognitive images influence affective image stored in consumers' mind. Thus, cognitive image and affective image are related one to another. Furthermore, by successfully influence tourists' affection, it can lead to re-visit action rather than visiting another island besides Bali. Third is different from the result from a literature review conducted by Llodra-Riere, et al. (2015) who indicates that uniqueness of destination will provide a tourist with underlying reason why the tourist should visit the destination over the destination. However, the result of this research is in line with study conducted by Qu et al., (2011) and Buyong \& Rajiani (2011) which have the same result that unique image significantly influences on affective image.

Thus, can be summarized that unique image has successfully influence and/or creating affective image of tourists. Bali was known for unique place and destination, if the government or tourism industry keep developing or creating a new unique destination in Bali, then every tourist that come to Bali will have the affection of the place regarding the unique image. Fourth is supported by literature review conducted by Llodra-Riere, et al. (2015) who indicates that motivation will influence the formation of tourists' cognitive image regarding the destination image of Bali. Beerli \& Martin (2004) also stated in their research that the perceived image or cognitive image will be formed through the image projected by the destination and the individual's own needs, motivations, prior knowledge, preferences, and other personal characteristics. The tourism industry in Bali has successfully created motivation of its tourists about Bali and influence the formation of cognitive image regarding Bali. The fifth is different from the previous study conducted by

Llodra-Riere, et al. (2015) who indicates that motivation will influence the formation of tourists' affective image regarding the destination image of Bali. Tourists' motivations are defined as a state of mind that encourages one to travel while able to provide a valid explanation for this decision to travel (Correia et al., 2013). Furthermore, tourists decide to travel because of the internal factor such as motivation that desired the tourist to fulfill the desire. The feeling of wanting to visit Bali is classified as affection. This statement in line with the study of Beerli \& Martin (2004), which suggested that motivation could direct and indirect influence on affective component of image formation. Santos (2013) on its research stated that effects of each variable which is motivation and cognitive image on variable affective image, has more impact on cognitive image influencing affective image rather than motivation directly influence the formation of affective image. Thus, the result of this research might be different if the motivation is indirectly influenced affective rather than motivation directly influence affective image. Sixth is supported by the previous research conducted by Llodra-Riere, et al. (2015), stated that positive motivation will influence the unique image of the destination. Buyong \& Rajiani (2011) stated that unique image defines what attributes or special characteristics that make the destination is special and differentiate from the other destination. Furthermore, previous researchers such as (Qu et al., 2011), confirm that the image of a destination that consists of unique image will directly influence intentions to revisit and 
recommend the destination to others. This uniqueness of Bali might trigger the motivation of tourists to visit Bali and if the tourist were satisfied with the unique image offered by Bali, tourist will develop the motivation and intention to revisit the island rather than another destination.

According to the theoretical framework, the information source is the first step to form construct mental regarding the destination before visiting and form the expectation about the destination. Soon the information will form the motivation which triggers the tourist to visit the destination by Chang et al. (2014). However, according to Schiffman \& Kanuk (1983), information sources also influence the formation of attitude which can be identified as affective. Direct and past experience, personal influence and exposure of mass media is important in the formation of tourists' attitude regarding the destinations. Affective image is influenced by motivation, cognitive image and unique images on this research models. Schiffman \& Kanuk (1983), knowledge and beliefs are likely to be a major aspect of the formation of attitude. In addition to the attitude formation, which is related to the affection, it needs to be realized and understand that each information source that individual obtained depends on its personality factors or internal factors. Thus, can understand that each variable on this research which are information sources, motivation, cognitive and unique image is will directly or indirectly influence the formation of affective image or consumer's attitude which is important for influencing tourist behavior regarding the destination which also can be changed based on the situation.

\section{CONCLUSSION}

According to the result and statistical test that have been done on the previous section, this research can be summed up as follows: 1) Information Source positively influence Motivation of tourist for visiting Bali. It can be concluded that the more complete information given by information sources, the level of tourist motivation to visit Bali will be increasing; 2) Cognitive Image positively influences Affective Image of Bali, a strong cognitive image will also strongly influence tourist affective image for visiting Bali; 3) Unique Image positively influences Affective Image of Bali. It means that the more unique the destination or places is, the more affection tourist feel about the place/ Bali; 4) Motivations have positively influence Cognitive Image of Bali. The more motivation tourist had for visiting a destination, the more cognitive image will had in return; 5) Motivation has not positively influence Affective Image of Bali, cognitive image influencing affective image; 6) Motivation has positively influence toward Unique Image Bali. It means that Bali is unique islands that have several unique place which make the island is different from another island in Indonesia. This uniqueness of Bali might trigger the motivation of tourist to visit Bali.

There are two practical implications in this research. First, the result explained that information source is giving the highest influencer of the formation of motivation supported by loading factor of 0.66 compared to the other loading factor, dimension FINFO4 on information sources consist of indicators or items which represent the UCG WEB or WEB. While dimension MOTI2 is the highest score is consisting of pleasure and physical. Therefore, tourists seek information about Bali from WEB since it is more effective and efficient compared seek information using traditional way by using books, travel agency and ask the information from relatives. The information that tourist had, soon formed the motivation to visiting Bali, more specifically to fulfill the desire of pleasure and physical such as relaxation, enjoyment and to escape from daily routine. For instance, the tourism industry in Bali, as well as the local people, should maintenance and keeps its performance by putting the best services in provide information about Bali using the web platform to its tourists. For complete information 
provided by the tourism industry in Bali will be used by tourists to develop the motivation to visit Bali rather than other destinations and influence the formation of destination images which is consisting of cognitive images, affective images, and unique images.

The second implication, according to the result of the processing data, compared to motivation as well as cognitive image which influence affective image, shows that the number of loading indicate that unique image is giving the higher influence and/or impact to affective image. Thus, according to the descriptive statistic of affect image and unique images, tourist will be more believe that Bali is pleasant, pretty, arousing and interesting if tourism sector in Bali keep improving the beautiful scenery of the beach, therefore, the tourist able to enjoy the original feature of Bali and also keep improving the proximity between one destination to another destination by making a high-way to make it easier for tourist to reach its destination to avoid traffic jams in the central of the city. Thus, this affection will be formed through feeling of Bali's uniqueness that makes tourist think if Bali is different from the other destination and the more tourist visited Bali, the more local revenue earned as the impact.

The Future recommendation is aimed for future research, as follows. (a) This research conducted by using Bali as the object of the research, future research should use another destination, for example BATU MALANG or RAJA AMPAT as the new object and the influence of social media toward tourists' motivation and image formation of the destination which consists of cognitive image, affective image, and unique image. (b) Future research could conduct international tourists in Surabaya to see how information source such as social media could significantly influence motivation and creating destination image consist of cognitive image, affective image, and unique image. (c) Future research should explore whether socio-demography, as well as psychological factors in tourists, have a positive influence on motivation in terms of formation affective image of destination as explained on the previous chapter (Buyong \& Rajiani 2011, Beerli \& Martin 2004). (d) There are many indicator are being deleted on preliminary test as well as on the confirmatory factor analysis for each dimension due to the items did not fulfill the minimum requirement which is loading factor $<0.5$, thus future research need to add number of the respondent to reduce the deleted indicator. (e) Future research could add and/or examine the effect of travel motivation and memorable tourism experience (Dani Dagustani et al. 2018); the effect of Motivation, Satisfaction and Perceived Value on Tourism Recommendation (Huang et al. 2015).

\section{ACKNOWLEDGMENTS}

Feel free to impress your gratitude to person(s) that help you in accomplish the research. Please keep the paragraph not more than 200 words.

\section{REFERENCES}

Adams, K., Snyder, J., Crooks, V., \& Johnston, R. (2015). Tourism discourse and medical tourists motivations to travel. Tourism Review, 70(2), 85-96.

Baloglu, S. (1999). The Relationship Between Destination Images and Sociodemographic and Trip Characteristics Of International Travelers. Journal of Vacation Marketing, 3(3), 221-233.

Beerli, A., Martin, J. D. (2004). Factors Influencing Destination Image. Annals of Tourism Research, 31(3), 657-681.

Buyong, E., Rajiani, I. (2011). Cognitive, Affective Evaluation in Forming Unique Destination Image Among Tourist Visiting Malacca. 7th Global Brand Conference. Oxford.

Chang, L. L., Backman, K. F., \& Huang, Y. C. (2014). Creative Tourism: A Preliminary Examination of Creative Tourists' Motivation, Experience, Perceived Value and Revisit 
Intention. International Journal of Culture, Tourism, and Hospitality Research, 8(4), 401-419.

Correia, A., Kozak, M., \& Ferradeira, J. (2013). From Tourist Motivations to Tourist Satiscation. International Journal of Culture, Tourism and Hospitality Research, 7(4), 411-421.

Dagustani, Dani, Kartini, D., Oesman, Y. M., \& Kaltum, U. (2018). Destination Image of Tourist: Effect of Travel Motivation and Memorable Experience. Etikonomi, ISSN 1412-8969; EISSN 2461-0771.

Eleonora, P., Di Pietro, L. (2013). From e-tourism to f-tourist: emerging issues from negative tourists' online reviews. Journal of Hospitality and Tourism Technology, 4(3), 211-227.

Gartner, W. C. (1993). Image Formation Process. Journal of Travel and Tourism Marketing, 2(2/3), 191-215.

Hair, J. F., Black, W. C., Babin, B. J., Anderson, R. E., \& Tatham, R. L. (1998). Multivariate Data Analysis (5th ed.). New Jersey: Prentice Hall.

Huang, Shuyue, Ye Shen, \& Chris Choi. (2015). The Effects of Motivation, Satisfaction and Perceived Value on Tourist Recommendation. Retrieved from https://scholarworks.umass.edu/ttra.

Khan, M. J., Chelliah, S., \& Ahmed, S. (2017). Factors Influencing Destination Image and Visit Intention Among Young Women Travelers: Role of Travel Motivation, Perceived Risks, and Travel Constraints. Asia Pacific Journal of Tourism Research, 22(11), 1139-1155. doi: https://doi.org/10.1080/10941665.2017.1374985.

Kim, H., Chen, J. S. (2016). Destination Image Formation Process: A Holistic Model. Journal of Vacation Marketing, 22(2), 154-166. doi: https://doi.org/10.1177/ 1356766715591870.

Kozak, N., Kozak, M. (2008). Information Sources Svailable To Visitors: A Segmentation Analysis. Tourism Review, 63(4), 4-12.

Llodra-Riere, I., Martínez-Ruiz, M. P., Jiménez-Zarco, A. I., \& Izquierdo-Yusta, A. (2015). Assessing the Influence of Social Media on Tourists' Motivations and Image Formation Of A Destination. International Journal of Quality and Service Sciences, 7(4), 458-482.

Oz, M. (2015). Social Media Utilization of Tourists for Travel-Related Purposes. International Journal of Contemporary Hospitality Management, 27(5), 1003-1023.

Pratminingsih, S. A., Rudatin, C. L., \& Rimenta, T. (2014). Roles of Motivation and Destination Image in Predicting Tourist Revisit Intention: A Case of Bandunglndonesia. International Journal of Innovation, Management and Technology, 5(1), 19-24. doi: https://doi.org/10.7763/IJIMT.2014.V5.479

Prayag, G., Ryan, C. (2011). The Relationship Between The 'Push' and 'Pull' Factors of a Tourist Destination: The Role of Nationality-an Analytical Qualitative Research Approach. Current Issues in Tourism, 14(2), 121-143. doi: https://doi.org/10. 1080/13683501003623802

Qu, H., Kim, L. H., \& Im, H. H. (2011). A model of destination branding: integrating the concepts of the branding and destination image. Tourism Management, 32(3), 465-476.

Santos, R. Dulce. (2013). Touristic Destination Image: A Study on Libson's Touristics Destination Image. ISCTE Business School.

Schiffman,L., Kanuk, \& Leslie L. (1983). Consumer Behavior. Second edition: Prentice Hall.

Wu, S.I., Yu-Hua, Z. (2014). The Influence of Tourism Image and Activities Appeal On Tourist Loyalty - A Study Of Tainan City In Taiwan. Journal of Management and Strategy, 5(4), 121-135.

Zhang, H., Wu, Y., \& Buhalis, D. (2017). A Model of Perceived Image, Memorable Tourism Experiences and Revisit Intention. Journal of Destination Marketing \& Management, 8, 326-336. doi: https://doi.org/10.1016/j.jdmm.2017.06.004 